\title{
Oral ATP administration improves blood flow response to exercise in an animal model and in resistance trained athletes
}

\author{
Ryan P Lowery ${ }^{1}$, Michael D Roberts ${ }^{2}$, Frank W Booth ${ }^{2,3}$, Jordan Joy ${ }^{1}$, Clayton L Cruthirds ${ }^{2}$, John A Rathmacher ${ }^{4}$, \\ Shawn M Baier ${ }^{4}$, John C Fuller ${ }^{4}$, Christopher M Lockwood ${ }^{5}$, Ralf Jäger ${ }^{6}$, Joshua E Dudeck ${ }^{1}$ Jacob M Wilson ${ }^{1^{*}}$ \\ From International Society of Sports Nutrition: 10th Annual ISSN Conference and Expo \\ Colorado Springs, CO, USA. 14-15 June 2013
}

\section{Introduction}

Extracellular adenosine triphosphate (ATP) is hypothesized to stimulate vasodilation by binding to endothelial ATP/UTP-selective P2Y2 receptors; a phenomenon which is posited to be accelerated during exercise. Nonetheless, no studies to our knowledge have delineated if supplemental ATP enhances the blood flow response to exercise. Herein, we used a rat model to examine how different dosages of acute oral ATP administration affected the femoral blood flow response prior to, during, and after an exercise bout. In addition, we performed a single dose chronic administration study in resistance trained athletes.

\section{Methods}

Animal study: After anesthesia male Wistar rats ( 300 g) were placed under isoflurane anesthesia and subsequently gavage-fed either $0.003 \mathrm{~g}(100 \mathrm{mg}$, species and body surface area-adjusted human equivalent dosage, $n=4)$, $0.012 \mathrm{~g}(400 \mathrm{mg}, \mathrm{n}=4), 0.031 \mathrm{~g}(1,000 \mathrm{mg}, \mathrm{n}=5)$, or 0.049 $\mathrm{g}(1,600 \mathrm{mg}, \mathrm{n}=5)$ of crystallized oral ATP disodium salt (Peak ATP ${ }^{\circledR}$, TSI, Missoula, MT); rats that were not gavage-fed were used as controls $(n=5)$. A blood flow probe was placed on the proximal portion of the right femoral artery and stimulation electrodes were placed in the right gastrocnemius muscle for an electrically-evoked plantarflexion exercise bout. Blood flow was then monitored continuously: a) $60 \mathrm{~min}$ prior to an electricallyevoked leg-kicking exercise (180 contractions), b) during and c) 90 min following the leg-kicking exercise. Areas

\footnotetext{
* Correspondence: jmwilson@ut.edu

'Department of Health Sciences and Human Performance, The University of Tampa, Tampa, FL, USA;

Full list of author information is available at the end of the article
}

under the pre-exercise, exercise, post-exercise, and total blood flow curves (AUC) were compared among conditions using one-way ANOVAs.

Human Study: In a pilot study, 12 college-aged resistance-trained participants were randomly assigned to an ATP or no ATP group. During week one, subjects were given no ATP, and $400 \mathrm{mg}$ of ATP daily for 12 weeks, and prior to an acute arm exercise bout (60 biceps curl contractions) at weeks $1,4,8$, and 12 . Ultrasonography determined volumetric blood flow and vessel dialation in the brachial artery was measured at rest before taking the supplement and 30 minutes after at rest, and then at 0,3 , and 6 minutes after the exercise.

\section{Results}

Animal Study: Rats fed 0.031 g (1000 mg human equivalent dosage) demonstrated significantly greater recovery blood flow ( $\mathrm{p}=0.007$ ) and total blood flow AUC values ( $\mathrm{p}=0.048)$ compared to CTL rats. Specifically, blood flow was elevated in rats fed $0.031 \mathrm{~g}$ versus CTL rats at 20 to 90 min post exercise when examining 10-min blood flow intervals $(\mathrm{p}<0.05)$. When examining within-group differences relative to baseline values, rats fed the $0.031 \mathrm{~g}(1,000$ $\mathrm{mg})$ and $0.049 \mathrm{~g}(1,600 \mathrm{mg})$ dosages exhibited the most robust increases in blood flow during exercise and into the recovery period.

Human study: At weeks 1,8 , and 12 there were significant differences in blood flow at 0 , and 3 minutes post exercise in the ATP supplemented relative to the control week (wk 0-No ATP), along with significant elevations in brachial dilation at those time points. 


\section{Conclusions}

These are the first data to our knowledge to demonstrate that oral ATP administration can increase blood flow, and is particularly effective during exercise recovery.

\section{Acknowledgements}

Supported by TSI (USA), Inc., Missoula, MT, USA.

\section{Authors' details}

'Department of Health Sciences and Human Performance, The University of Tampa, Tampa, FL, USA;. ${ }^{2}$ Department of Biomedical Sciences, College of Veterinary Medicine, University of Missouri, Columbia, MO, USA. ${ }^{3}$ Department of Nutrition and Exercise Physiology, University of Missouri, Columbia, MO,

USA: ${ }^{4}$ Metabolic Technologies Inc, lowa State University Research Park, Ames, IA, USA; : ${ }^{5}$ AP Nutrition LLC, Missoula, MT, USA. ${ }^{6}$ Increnovo LLC, Milwaukee, WI, USA.

Published: 6 December 2013

doi:10.1186/1550-2783-10-S1-P16

Cite this article as: Lowery et al: Oral ATP administration improves blood flow response to exercise in an animal model and in resistance trained athletes. Journal of the International Society of Sports Nutrition 2013 10(Suppl 1):P16.

Submit your next manuscript to BioMed Central and take full advantage of:

- Convenient online submission

- Thorough peer review

- No space constraints or color figure charges

- Immediate publication on acceptance

- Inclusion in PubMed, CAS, Scopus and Google Scholar

- Research which is freely available for redistribution

Submit your manuscript at www.biomedcentral.com/submit
C Biomed Central 